Çukurova Üniversitesi Mühendislik Mimarlık Fakültesi Dergisi, 34(2), ss. 255-265, Haziran 2019

Çukurova University Journal of the Faculty of Engineering and Architecture, 34(2), pp. 255-265, June 2019

\title{
Farklı Yöntemler ile Üretilen MgO Takviyeli Alüminyum Kompozitlerde Mekanik Davranışların Karşılaştırılması
}

\author{
Muharrem PUL ${ }^{* 1}$ \\ ${ }^{1}$ Kırlkkale Üniversitesi, Kırıkkale Meslek Yüksekokulu, Elektrik ve Enerji Bölümü, Kırlkkale
}

Geliş tarihi: 29.04.2019 Kabul tarihi: 28.06.2019

Öz

Bu deneysel çalışmada vakumlu infiltrasyon, karıştırmalı döküm ve toz metalurjisi teknikleriyle üretilmiş olan $\mathrm{MgO}$ parçacık takviyeli alüminyum kompozitlerin mekanik davranışları karşılaştırılmıştır. $\mathrm{Bu}$ amaçla daha önce üç farklı yöntemle üretilmiş olan; \%5, \%10 ve \%15 MgO takviyeli alüminyum kompozitlerin ilk olarak porozite (gözenek) miktarları ölçülmüştür. Daha sonra sırasıyla sertlik ölçümleri, çapraz kırılma ve abrasif aşınma deneyleri yapılmıştır. Elde edilen deney sonuçlarına göre; kompozit yapı içerisindeki $\mathrm{MgO}$ takviye oranının artmasıyla porozite ve aşınma kayıpları artış göstermiştir. Ayrıca MgO takviye oranının artmasıyla sertlik değerleri artarken kırılma dayanımları azalmıştır. Üç farklı yöntemle üretilen kompozitler içerisinde en düşük mekanik performans toz metalurjisi tekniği ile üretilen kompozitlerde gözlenmiştir. Genel olarak en yüksek mekanik değerler karıştırmalı döküm yöntemiyle üretilen kompozitlerden elde edilmiş̧ir.

Anahtar Kelimeler: Kompozit, Alüminyum, MgO, Porozite, Mekanik özellik

\section{Comparison of Mechanical Behavior of MgO Reinforced Aluminum Composites Produced by Different Methods}

\begin{abstract}
In this experimental study, the mechanical behaviours of $\mathrm{MgO}$ particle reinforced aluminium composites produced by vacuum infiltration, blended casting and powder metallurgy techniques were compared. For this purpose, previously produced by three different methods; Porosity (porosity) amounts of $5 \%, 10 \%$ and 15\% MgO reinforced aluminium composites were measured first. Then, respectively, hardness measurements, transverse rupture and abrasive wear tests were performed. According to the obtained test results; porosity and wear losses increased with increasing $\mathrm{MgO}$ reinforcement ratio in the composite structure. Furthermore, with the increase of MgO supplementation, hardness values increased and fracture strengths decreased. Among the composites produced with three different methods, the lowest mechanical performance was observed in the composites produced by powder metallurgy technique. Generally, the highest mechanical values were obtained from the composites produced by the stir casting method.
\end{abstract}

Keywords:Composite, Aluminium, MgO, Porosity, Mechanical property

*Sorumlu yazar (Correspondingauthor): Muharrem PUL, mpul@kku.edu.tr 


\section{GíRiş}

Endüstri alanındaki gelişmelerin büyük hızla devam ettiği çağımızda bütün üretim sektörlerinin temel elemanı kullandikları malzemelerdir. Son yıllarda geleneksel malzemelere alternatif olan kompozitler üstün özellikleri sayesinde çok geniş kullanım sahası bulmaktadır. Metal matrisli ve parçacık takviyeli kompozitler de bunlardan bir çeşidi temsil etmektedir. Özellikle alüminyum gibi hafif metaller ve seramik esaslı takviye elemanları ile güçlendirilmiş kompozitler otomotiv savunma ulaştırma havacılık gibi pek çok endüstri dalında yaygın olarak tercih edilmektedir. $\mathrm{Bu}$ tür kompozitler genellikle katı faz ve sıvı faz üretim yöntemleri ile üretilmekte olup; basınçlı, basınçsız ve vakumlu infiltrasyon, karıştırmalı döküm, basınçlı döküm, toz metalurjisi yöntemleri başlıca üretim çeşitlerini oluşturmaktadır. $\mathrm{Bu}$ alandaki gelişmeler ve yapılan bilimsel araştırmalar her geçen gün artmaktadır. Yukarıda bahsi geçen kompozit üretim yöntemleri uygulanarak yapılan çalışmalara ait literatür özetleri aşağıda verilmiştir.

\section{2. ÖNCEKİ ÇALIŞMALAR}

Pul yapmış olduğu çalışmada, alüminyum matris içerisine $\% 5, \% 10, \% 15$ oranlarında $\mathrm{MgO}$ takviye ederek vakumlu infiltrasyon yöntemi ile kompozitler üretmiştir. Kompozitlerin mikro yapılarını, mekanik özelliklerini ve işlenebilirlik davranışlarını incelemiştir. Kompozit yapı içerisindeki $\mathrm{MgO}$ takviye oranının artması homojeniteyi olumlu etkilerken, poroziteyi arttırmıştır. Yüksek takviye oranları kırılma dayanımı ve işlebilme kabiliyeti üzerinde olumsuz etki yapmıştır. Genel olarak en optimum sonuçlar \%10 takviyeli kompozitten elde edilmiştir [1]. Aydın yaptığı çalışmada, alüminyum esaslı kompozitleri, \%55 MgO takviye oranında ve siv1 alaşım içerisine ayrıca $\% 5 \mathrm{Mg}$ ekleyerek vakumlu infiltrasyon ile üretmiştir. Çalışmadan elde edilen sonuçlar, hacimce \%50-\%55 MgO ilavesinin, alüminyum kompozitlerin üretiminde uygun olduğunu göstermiştir. \%50-55 MgO takviye oranında, $700{ }^{\circ} \mathrm{C}-800 \quad{ }^{\circ} \mathrm{C}$ siv1 matris sicaklık aralığında ve $300 \mathrm{mmHg}-500 \mathrm{mmHg}$ arasındaki vakum değerinde ve 3 dakikalık infiltrasyonsüresinin uygun olduğu rapor edilmiştir [2]. Acılar ve arkadaşları çalışmalarında, vakumlu infiltrasyon yöntemi ile üretilen $\mathrm{Al}-\mathrm{SiCp}$ katkılı kompozitlerin kompakt karışımına $\mathrm{Mg}$ tozunun, sıvı metale $\mathrm{Mg}$ ilavesinin ve $\mathrm{SiC}$ oksidasyonunun tesirini incelemiştir. Kompozitlerde sertlik, yoğunluk, gözeneklilik ve mikroyapı incelemeleri yapılmıştır. Kompakta Mg tozu, sıvı metale $\mathrm{Mg}$ ilavesinin ve $\mathrm{SiC}$ oksidasyonunun infiltrasyonu olumlu etkilediğini, infiltrasyon mesafesini, kompozit yapının sertliğini ve yoğunluğunu arttırdığını ayrıca, poroziteninde azaldığını belirtmişlerdir [3]. Montoya ve arkadaşları çalışmalarında, basınçsız infiltrasyonla üretilen $\mathrm{Al} / \mathrm{SiC}$ kompozit numunelerin parçacık boyutu dağılımının yüzey sertliğine etkisinin yanı sıra, silisyum karbür (SiCp) parçacıklarının kırılma tokluğunu araştırmışlardır. Sonuçta, tanecik boyutlu dağılımların doğrusal olarak yüzeyde sertlik gösterdiğini, mikro sertliklerin ve kırılma tokluğunun ise parabolik olarak değişen yoğunlukta olduğu ifade edilmiştir. Kompozit yüzeyindeki sertlik davranışına, matris malzemesinin sertliği ve $\mathrm{SiC}$ parçacıklarının birbirine çarpmasının neden olduğu belirtilmiştir [4]. Demir ve Altınok yaptıkları çalışmada, Al esaslı $\mathrm{Al}_{2} \mathrm{O}_{3} / \mathrm{SiC}$ parçacık takviyeli kompozitleri basınçlı infiltrasyon ile üretmişlerdir. Deneyler sonucunda, infiltrasyon sicaklığının önemli bir parametre olduğunu ifade ederek, yükselen infiltrasyon sicaklıklarında kompozit yapının yoğunluğunun ve kopma dayanımlarının arttığını tespit etmişlerdir. \%13 takviye oranında, $800{ }^{\circ} \mathrm{C}$ sıvı metal sicaklığında ve $3 \mathrm{MPa}$ infiltrasyon basıncında $558 \mathrm{MPa}$ kopma dayanımı elde edilmiştir [5]. Hashim ve arkadaşları çalışmalarında, A359 alüminyum matrisli SiC parçacık takviyeli kompozitleri karıştırmalı döküm yöntemiyle üretmiştir. A359 matris alaşımının $\mathrm{SiC}$ parçacıklarını 1slatmasında sıvı matris içerisine ilave edilen magnezyumun etkilerini araştırmıştır. Sonuçta, magnezyum alaşımını 1slatmada etkin rol oynadığını ve karıştırma işleminin, sıvı metalin döküm işlemine kadar aralıksız devam etmesinin gerekli olduğunu belirtmişlerdir. Ayrıca, dökülen kompozit malzemenin soğuma hızının azaltılmasının 1slatmayı olumlu etkilediğini, $\mathrm{SiC}$ parçacık miktarının artmasının ise 1slatmayı olumsuz etkilediğini ifade etmişlerdir. [6]. Sur ve 
arkadaşları yaptıkları çalışmada, 2014 alüminyum alaşımı matrisli ve 29,45 ve $110 \mu \mathrm{m}$ tanecik boyutlarında SiC takviyeli kompozitleri karıştırmalı döküm yöntemiyle elde etmişlerdir. Kompozitlerin üretim sürecinde artan tanecik boyutu ve azalan takviye elemanı ağırlık oranının karıştırmalı döküm üretim işlemini kolaylaştırdığını belirtmişlerdir. Azalan tanecik boyutu ve artan takviye ağırlık oranı ile kompozit yapının sertlik değeri artış göstermiştir. Fakat aynı durumda, gözenekliliğin ve takviye topaklanmasının arttığı ve homojen dağılımın azaldığ 1 belirtilmiştir [7]. Davidson ve Regener çalışmalarında, toz metalurjisi yöntemi ile metal matrisli kompozitler üretmiştir. Matris malzemesi olarak, $45 \mu \mathrm{m}$ tanecik boyutunda 6061 kalite alüminyum alaşımı ve takviye elemanı olarak ta bakır kaplamalı ve kaplamasız, 7-23 $\mu \mathrm{m}$ parçacık boyutunda SiC kullanmışlardır. Bakır kaplı ve kaplamasız SiCp takviyenin kompozitin mikroyap1 ve mekanik özelliklerine etkisini mukayese etmişlerdir. Parçacık boyutu $23 \mu \mathrm{mSiCp}$ takviyeli kompozitlerde bakır kaplı SiCp takviyeli kompozitlerin daha iyi performans gösterdiğini, $7 \mu \mathrm{m}$ boyutlarındaki kaplamasız SiCp takviyeli kompozitte ise çekme dayanımının daha iyi olduğunu ifade etmişlerdir [8]. Günay yaptığı çalışmada, toz metalurjisi ile metal matrisli kompozitler üretmiştir. Matris malzemesi olarak ortalama $63 \mu \mathrm{m}$ boyutlarında Alumix 231 (Al-Si alaşımı) tozu, takviye elemanı olarakta ortalama 20,1 $\mu \mathrm{m}$ tane boyutunda $\mathrm{SiC}$ parçacıkları kullanmıştır. Ağırlıkça \%5, \%10, \%15 SiC takviye oranlarında üretilen kompozit numunelerin mikroyapı ve bazı mekanik özellikleri araştırılmıştır. Mikroyapı incelemelerinde parçacık dağılımının tüm numunelerde homojen olduğu ancak bir miktar gözenekliliğin oluştuğu ifade edilmiştir. En yüksek sertlik değeri \%15 SiC takviyeli numunede elde edilmiştir. En yüksek çapraz kırılma dayanımı takviyesiz Alumix 231 alaşımından üretilen numunede ölçülürken, en düşük çapraz kırılma dayanımı $\% 15 \mathrm{SiC}$ takviyeli numuneden elde edilmiştir [9]. Yukarıda verilen çalışmaların dışında pek çok farklı araştırma yapılmış ve sonuçları akademik ortamda paylaşılmıştır [10-16].
Ancak yapılan literatür araştırmalarında metal matrisli parçacık takviyeli kompozitlerin üretim yöntemlerinin kıyaslandığı bir çalışmaya rastlanmamıştır. Makaleye konu olan bu çalışmada ise; daha önce üretilmiş ve her biri ayrı araştırma konusu olan üç farklı kompozit üretim yöntemi, aynı matris ve takviye malzemesi kullanılarak ve aynı deney parametreleri ile bazı mekanik özellikler yönünden mukayese edilmiştir.

\section{MATERYAL VE METOT}

Bu deneysel çalışmada kullanılan kompozit üretme yöntemlerinin hepsinde aynı özellikte matris malzemesi AA 1050 (ETİAL 5) kalite alüminyum ve aynı özellikte takviye elemanı $\mathrm{MgO}$ (magnezyum oksit) kullanılmıştır. Çizelge 1'de deney malzemelerine ait özellikler verilmektedir.

Çizelge 1. Deney malzemelerine ait teknik özellikler

\begin{tabular}{|l|c|}
\hline \multicolumn{2}{|c|}{ AA 1050 (ETİAL 5) } \\
\hline $\mathrm{Cu} \%$ & 0,05 \\
\hline $\mathrm{Fe} \%$ & 0,40 \\
\hline $\mathrm{Si} \%$ & 0,25 \\
\hline $\mathrm{Zn} \%$ & 0,05 \\
\hline $\mathrm{Mn} \%$ & 0,05 \\
\hline $\mathrm{Ti} \%$ & 0,04 \\
\hline $\mathrm{Al} \%$ & 99,5 \\
\hline Magnezyum oksit (Magnezya) \\
\hline MgO \% & 98 \\
\hline Fe \% & 0,6 \\
\hline SiO \% & 1,0 \\
\hline CaO \% & 0,4 \\
\hline Akma (Mpa) & $20-35$ \\
\hline Çekme (Mpa) & $65-80$ \\
\hline Uzama (\%50) & 38 \\
\hline Sertlik (Brinell) & $20-21$ \\
\hline
\end{tabular}

\subsection{Kompozit Malzeme Üretim Yöntemleri}

Vakumlu İnfiltrasyon: Kompozit malzemelerin üretiminde; matris malzemesi olarak \%99,5 saflığında 149-210 $\mu \mathrm{m}$ tane büyüklüğünde alüminyum tozu ve 105-149 $\mu \mathrm{m}$ tane boyutunda $\mathrm{MgO}$ tozu kullanılmıştır. İlk aşamada, belirlenmiş olan takviye hacim oranlarında hazırlanan 
kompozit toz karıșımlar vakum tüpleri içerisine yerleştirilmiştir. Aynı zamanda içerisinde matris elemanı alüminyum külçe malzemelerinin bulunduğu pota ergitme ocağı içerisinde isitılmaya başlanmıştır. Pota içerisindeki AA1070 matris malzemesi $750{ }^{\circ} \mathrm{C}$ sıcaklığa çıkıncaya kadar 1 sıtma işlemi devam etmiş ve alüminyumun sıvı hale gelmesi sağlanmıştır. Bu sırada deney borularının vakum tesisatına bağlanması tamamlanarak matris elemanı alüminyumun ergitildiği pota içerisine deney boruları daldırılarak, 10 dakika süre ile 600 $\mathrm{mmHg}$ vakum uygulaması yapılmıştır. Bu sürede deney borusu içerisindeki Al-MgO parçacıkları arasına Sıv1 alüminyum vakumla infiltre edilerek istenilen kompozit numuneler üretilmiştir. Şekil 1'de infiltrasyon deney tertibatının şematik çizimi verilmiştir [17].



Şekil 1. Vakumlu infiltrasyon deney düzeneği [17]

Karıştırmalı Döküm: Kompozit numunelerin üretiminde ilk olarak, AA1050 külçe matris malzemesi pota içerisine yerleştirilerek ergitme işlemi başlatılmıștır. Isıtma işlemi sıvı matris sıcaklığı $750{ }^{\circ} \mathrm{C}$ 'ye çıkıncaya kadar devam ettirilmiştir. $\mathrm{Bu}$ arada matris ile takviye elemanı tozları arasındaki 1slatmayı kolaylaştırmak için $\% 1,0$ ağırlık oranında saf magnezyum pota içerisine ilave edilmiştir. Daha sonra karıştırıcı pervane sıvı metal AA1050 içerisine daldırılarak karıştırma işlemine başlanmıştır. Karıştırma hızı 400 rpm'ye çıkarılarak, karıştırma işlemi devam ederken, takviye oranı miktarlarına göre 149-210 $\mu \mathrm{m}$ boyutundaki MgO tozu, sıv1 metal içerisine ilave edilmiştir. Sıvı metal içerisine ilave edilen $\mathrm{MgO}$ parçacıklarının homojen dağılımını sağlamak için, karıştırma işlemine 10 dakika süreyle devam edilmiştir. Karıştırma tamamlandiktan hemen sonra, pota ocak içerisinden çıkarılarak, kompozit karışım daha önce hazırlanan kalıplar içerisine dökülerek oda sıcaklığına soğumaya bırakılmıştır. Aynı üretim işlemleri her $\mathrm{MgO}$ takviye oranı için uygulanmıştır. Şekil 2'de karıştırmalı döküm deney tertibatının şematik çizimi verilmiştir [18].

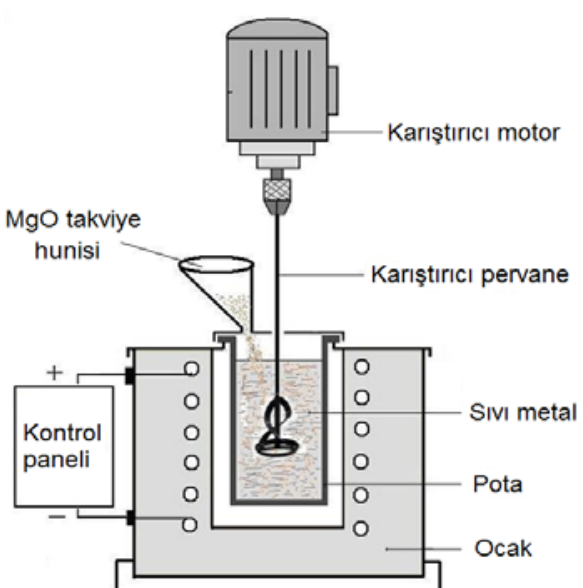

Şekil 2. Karıştırmalı döküm deney düzeneği [18]

Toz Metalurjisi: Toz metalurjisi deneylerinde de infiltrasyonda olduğu gibi 149-210 $\mu \mathrm{m}$ boyutunda AA1050 tozları ve 105-149 $\mu \mathrm{m}$ boyutunda MgO tozları kullanılmıştır. İlk olarak \%5, \%10 ve \%20 $\mathrm{MgO}$ takviye oranlarına göre kompozit karışımlar hazırlanarak çelik bilyeli tamburlu tip karıştırıcıya konulmuştur. Karıştırma işlemi, $8 \mathrm{~mm}$ çapında zirkonya $\left(\mathrm{ZrO}_{2}\right)$ esaslı bilyeler $5 / 1$ (bilye /toz) ağırlık oranı uygulanarak, $300 \mathrm{rpm}$ hızda ve 2 saat süreyle gerçekleştirilmiştir. Ayrıca karışım tozlarının tambur ve kalıp yüzeylerine sıvanmasını önlemek ve presleme kalıbında kaymayı kolaylaştırmak amacıyla toz karıșımların içerisine $\% 1,0$ oranında toz çinko stearat yağlayıcı olarak ilave edilmiştir. Karıştırma işlemi tamamlandıktan sonra, kompozit karışımlar hidrolik preste 600 $\mathrm{MPa}$ basınç altında sıkıștırılarak deney numuneleri üretilmiştir. Üretilen kompozit numuneler $580{ }^{\circ} \mathrm{C}$ 'de, argon atmosferi altında, $120 \mathrm{~min}$ süreyle sinterleme işlemine tabi tutularak kompozitlerin üretim süreci tamamlanmıştır. Şekil 3'te toz metalurjisi üretim aşamaları sembolik olarak gösterilmektedir. 

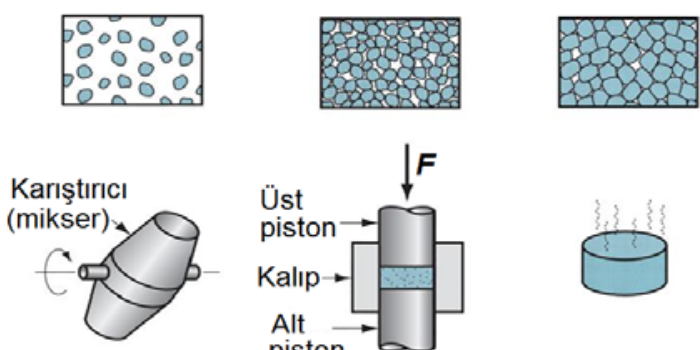

Toz

karıştırma

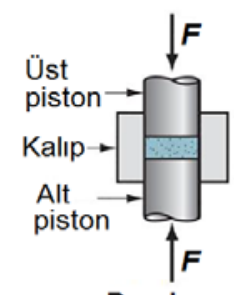

Presleme

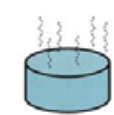

Sinterleme

Şekil 3. Toz metalurjisi üretim aşamaları [19]

\subsection{Mekanik Deneyler}

İlk aşamada Arşimet Prensibi’ne göre önce numunelerin havadaki ağırlığı daha sonra da sudaki ağırlığı hassas terazi ile ölçülmüş ve (\%) cinsinden teorik yoğunlukları belirlenmiştir. Daha sonra yapılacak mekanik ölçüm ve deneyler için üretilen kompozit malzemelerden deney standartlarına uygun olarak deney numuneleri hazırlanmıştır.

İlk olarak Brinell Yöntemi kullanılarak sertlik ölçümleri yapılmıştır. Sertlik ölçümleri EN ISO 4498 [20] ve TS EN ISO 6506-1 [21] standartlarına uygun olarak, Qness Q250M model sertlik ölçme cihazında yapılmıştır. Sertlik ölçümlerinde $2,5 \mathrm{~mm}$ çaplı bilya uç, $62,5 \mathrm{~kg}$ yük ve 14 saniye deney süresi uygulanmıştır. Sertlik ölçümlerinde her numune üzerinde 5 farklı noktadan ölçüm yapılarak ortalama değer hesaplanmıştır.

Mekanik özellik belirleme deneylerinin ikinci aşamasında ASTM-B 528-05 [22] standardına göre çapraz kırılma (üç nokta eğme) deneyleri gerçekleştirilmiştir. Çapraz kırılma deneyleri, $0,05 \mathrm{kN} / \mathrm{sn}$ yükleme hızıyla ELE marka hidrolik preste gerçekleştirilmiştir.

Üçüncü aşama deneyler, kompozit numunelerin aşınma davranışlarını belirlemek amacıyla yapılmıştır. Aşınma deneyleri, pin-on-disk yöntemi ile $30 \mathrm{~N}$ yük uygulanarak yapılmıştır. Aşınma deneylerinde, $100 \mu \mathrm{m} \quad(149 \mathrm{mesh})$ aşındırıcı tane boyutuna sahip, $\mathrm{Al}_{2} \mathrm{O}_{3}$ zımpara kullanılmıştır. Her kompozit numune, 0,2 $\mathrm{ms}^{-1}$

kayma hizında ve 60 saniye süre boyunca deneye tabi tutularak aşınma kayıpları kaydedilmiştir.

\section{BULGULAR VE TARTIŞMA}

\subsection{Porozite Oranlarının Değerlendirilmesi}

Üç farklı takviye oranında üretilmiş olan kompozit malzemelerin Arşimet prensibine göre ölçülen porozite oranlarını gösteren grafik Şekil 4'te verilmiştir. Şekil 4 ve sonrasında gelecek olan Şekil 5, 6 ve 8 içerisindeki Vİ (Vakumlu İnfiltrasyon), KD (Karıştırmalı Döküm), TM (Toz Metalurjisi) terimlerinin kısaltması olarak kullanılmıştır.

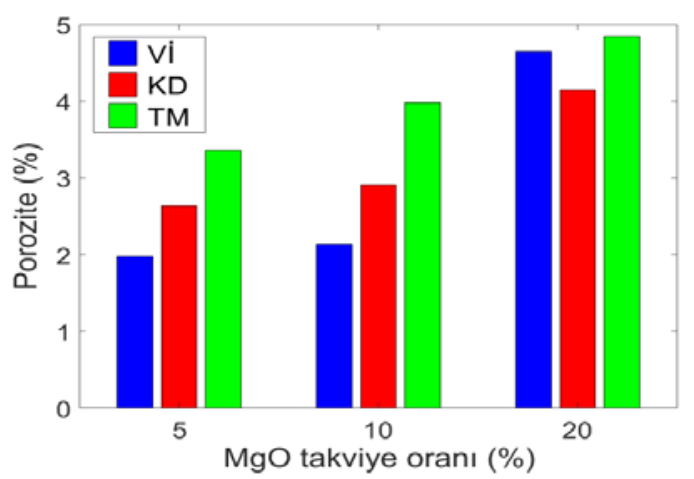

Şekil 4. VI, KD ve TM ile üretilen kompozitlerin MgO takviye oranına göre porozite miktar1

Şekil 4'teki grafiğe bakıldığında ilk göze çarpan, $\mathrm{MgO}$ takviye miktarındaki artışa bağlı olarak kompozitlerdeki gözenek oranlarının da artmış olmasıdır. $\mathrm{Bu}$ durum parçacık takviyeli bu tür kompozit yapılarda genellikle meydana gelmektedir [1,4,7,23-27]. Parçacık takviyeli metal matrisli kompozitlerin üretimi sırasında karşılaşılan en önemli sorunlardan birisi matris malzemesinin seramik esaslı takviye parçacıklarını tam veya yeterli 1slatamamasıdır. Kompozit yapı içerisindeki 1slatma problemi genellikle beraberinde poroziteyi getirmektedir. Islatma olayı matris malzemesinin takviye parçacığının sarması ve bütünleşmesi anlamına geldiğinden, olamayan ıslatma matris malzemesi ile takviye parçacığ arasında boşluk oluşturan bir ara yüzey anlamına gelmektedir. 
Porozite oranını etkileyen diğer husus ise kompozit yapı içerisindeki takviye elemanı topaklanmalarıdır. Takviye topaklanmalarının olduğu bölgelerde genellikle matris elemanı nüfuziyeti çok az olmakta veya olamamaktadır. Topaklanan takviye parçacıklarının kendi aralarında meydana getirdikleri boşluklar ciddi oranda poroziteye yol açmaktadır. $\mathrm{Bu}$ genel bilgilendirmeden sonra kompozit üretim yöntemleri yönünden porozite oranlarını değerlendirebiliriz.

Vakumlu infiltrasyonda diğer yöntemlere göre $\% 5$ ve $\% 10$ takviye değerlerinde porozitenin daha düşük olduğu Şekil 4'teki grafiklerden görünmektedir. Bunun sebebi olarak ilk etapta infiltrasyon yönteminin şekli ve parametrelerinin etkisi akla gelmektedir. Bu yöntemde infiltrasyon borusu içerisine doldurulmuş olan AA1070 ve $\mathrm{MgO}$ tozlarının hareketinin sinırlanması ve $750{ }^{\circ} \mathrm{C}$ deki sıvı metalin akıcılık etkisiyle takviye ve matris partiküllerin arasına daha rahat nüfuz etmesi boşluk oranlarının daha az olmasında etkili olmuştur. Diğer etken ise sıvı metalin uygulanan vakumun yardımıyla güç kazanarak parçacıklar arasına daha rahat ulaşabilmesidir. Ancak $\mathrm{MgO}$ takviye oranının \%20'ye çıkmasıyla porozite oranı ani bir atış göstermiştir. Takviye oranının artmasıyla boru içerisindeki kompakt $\mathrm{AA} 1050+\mathrm{MgO}$ tozları arasındaki boşluklarda, $\mathrm{MgO}$ tozlarının düzgün olmayan köşeli şeklinden dolayı artış göstermiştir. İnfiltrasyon sürecinde uygulanan $500 \mathrm{mmHg}$ vakum değerinde, siv1 metalin boşluklu yapının tamamına nüfuz edemediğini ve vakum değerinin bir miktar yetersiz kaldığı değerlendirilmektedir. Yapılan başka çalışmalarda benzer sonuçlara dikkat çekilmiştir $[1,4]$.

Bir başka hususta Vİ yönteminde işlemin uygulanması sırasında vakum borusu içerisinde bulunan takviye elemanı $\mathrm{MgO}$ parçacıklarının bir kısmının vakumun itme etkisiyle yukarıya doğru sürüklenerek bazı bölgelerde yoğunlaşması ve takviye topaklanmalarına sebep olmasidır. Bu durumda topaklanmaların olduğu yerlerde siv1 matris metalinin düşük nüfuziyeti ve yetersiz ıslatma meydana gelerek geniş porozite bölgeleri oluşturması muhtemeldir. Hal böyle olunca da kompozit yapı içerisinde homojen olmayan bir dağılım ve dengesiz mikroyapılar ortaya çıkabilmektedir. Bazen bu tür kompozit yapıların mekanik deneylerinde beklenmeyen sonuçlar ile karşılaşılmaktadır.

Karıştırmalı döküm tekniğinde ise en çok şikayet edilen hususların başında yine islatma problemi gelmektedir [1,6]. Bu yöntemde her ne kadar takviye elemanı parçacıkları sıvı metal içerisine atılıyor olsa da karıştırma sırasında meydana gelen vorteks ve sıvı matris ile takviye parçacıları arasındaki yoğunluk farkından dolayı meydana gelen takviye çökelmesi nedeniyle hem kötü homojenite hem de takviye topaklanması meydana gelmektedir. Takviye topaklanması poroziteye önemli ölçüde olumsuz etki yapmaktadır $[1,6,7,23,26,27]$.

Doğal olarak $\mathrm{MgO}$ takviye miktarının artmasıyla porozite oranları da artış göstermiştir. Bu konuda yapılan çalışmalarda sıvı metal içerisine ilave edilen takviye elemanı parçacığı boyutunun da etkili olduğu, parçacık boyutu küçüldükçe takviye elemanının sıvı metal içerisine karışmasının zorlaştığı görülmüştür. Diğer bir husus ise karıştırmalı döküm sırasında meydana gelen oksitlenmedir. Karıştırma sırasında pervanenin oluşturduğu vorteks ile sıvı metal içerisine sürekli hava girişi olmakta ve havanın içerisindeki oksijenin tesiri ile oksitlenme olayı gerçekleşmektedir. Karıştırmalı döküm yönteminde işlem sırasında argon, azot vb. inört gazlar kullanılarak havanın ortamdan uzaklaştırılması gerekmektedir. Böylece oksitlenme ortadan kaldırılabilir veya en aza indirilerek kompozit yapı içerisindeki porozite oranlarının düşürülebileceği değerlendirilmiştir.

\subsection{Sertlik Ölçümlerinin Değerlendirilmesi}

Üç farklı MgO takviye oranında üretilmiş olan alüminyum kompozit malzemelerin Brinell Yöntemine göre ölçülen sertlik miktarlarını gösteren grafik Şekil 5 'te verilmiştir. 


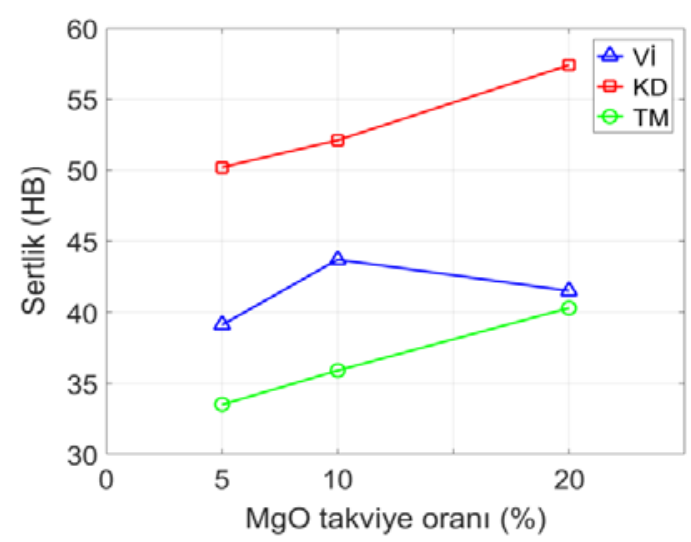

Şekil 5. VI, KD ve TM ile üretilen kompozitlerin $\mathrm{MgO}$ takviye oranına göre sertlikleri

Şekil 5'teki grafiğe bakıldığında ilk göze çarpan, $\mathrm{MgO}$ takviye miktarındaki artışa bağlı olarak kompozitlerdeki sertlik değerlerinin de artmış olmasıdır. Ancak vakumlu infiltrasyon (Vİ) yöntemi ile üretilen kompozitlerde bu durum farklıdır. Özellikle $\mathrm{MgO}$ takviye oranının \%20'ye çıkmasıyla sertlik değerinin biraz daha yükselmesi beklenirken aksine azalmıştır. Normal şartlarda kompozit yapı içerisindeki sert faza sahip takviye elemanı miktarı arttıkça kompozit yapının genel olarak sertlik değerinin artış göstermesi beklenen ve literatürde yer alan bir sonuçtur ve diğer iki yöntemde de (KD ve TM) beklendiği gibi olmuştur $[1,4,7,23,26,27]$. Vİ yöntemiyle üretilen kompozit numunelerdeki yüksek porozite miktarının sertlik değerlerini doğrudan etkilediği söylenebilir. Başlık 3.1'de kompozit yapıların porozite miktarları değerlendirilirken bu hususa dikkat çekilmiştir. Boşluklu porozifmikroyapı ve bu yapıya bağlı olarak, sertlik ölçmelerinde kullanılan ölçüm probunun sik s1k porozif bölgelere rastlaması ile sertlik değerleri düşük ölçülmüştür. Şekil 4'teki grafiğe bakıldığında Vİ yöntemiyle üretilmiş $\% 20 \mathrm{MgO}$ takviyeli kompozit numunenin yüksek porozite değeri görülmektedir. Dolayısıyla porozite ve sertlik değerleri arasındaki ilişki ortaya çıkmıştır. Grafikteki sertlik değerlerine göre, KD yönteminin diğer yöntemlere göre sertlik yönünden daha yüksek olduğu, en düşük sertlik değerlerinin de TM yöntemiyle elde edildiği sonucu çıkmıștır. Mekanik özellikleri yüksek olması istenen bu tür seramik parçacık takviyeli alüminyum esaslı kompozit malzemelerde, sertlik yönünden en yüksek değerlerin karıştırmalı döküm yöntemiyle elde edilebileceği ifade edilebilir.

\section{3. Çapraz Kırılma Yükü}

Mekanik özelliklerin belirlenmesinde ikinci aşama deneylerde çapraz kırılma (üç nokta eğme) deneyleri yapılmıştır. Üç farklı $\mathrm{MgO}$ takviye oranında üretilmiş olan kompozit numunelerin çapraz kırılma deneylerinden elde edilen kırılma yükü değerleri Şekil 6'daki grafiklerde verilmiş̧ir.



Şekil 6. Vİ, KD ve TM ile üretilen kompozitlerin $\mathrm{MgO}$ takviye oranına göre kırılma yükleri

Şekil 6'daki grafik incelendiğinde, $\mathrm{MgO}$ takviye miktarındaki artışa bağlı olarak her üç yöntemde de kırılma yükü (dayanımı) değerlerinin ciddi oranda düşmesidir. Bu durumu ilk olarak kompozit yapılardaki porozite miktarlarına atfetmek mümkündür ve literatürde benzer sonuçlar yer almaktadır $\quad[1,4,6,7,9,23,25-27]$. Şekil 4'e bakıldığında; bütün takviye oranlarında en yüksek porozite değerleri TM yöntemiyle üretilmiş kompozitlerde ölçülmüştür. Şekil 6'da en düşük kırılma yükü değerleri yine TM yöntemiyle üretilmiş kompozitlerden elde edilmiştir. Kompozit yapı içerisindeki poroziteler(boşluk ve gözenekler) doğal olarak mekanik mukavemeti düşürmektedir. Ancak Vİ yönteminin $\% 20 \mathrm{MgO}$ takviye oranındaki yüksek porozite değeri, sertlik sonuçlarında olduğu gibi burada da etkisini göstermiş ve en düşük kırılma yükü değeri Vİ yöntemiyle üretilmiş $\% 20 \quad \mathrm{MgO}$ takviyeli 
kompozitte kaydedilmiştir. Dolayısıyla porozite değerleri ile kırılma yükü değerleri arasında doğrudan ilişki olduğu görülmektedir.

Kırılma yükü değerlerini etkileyen diğer husus $\mathrm{MgO}$ takviye elemanı parçacıklarının şeklidir. MgO parçacıklarının keskin köşeli yapısı kompozit yapı içerisinde doğal olarak çentik ve mikro çatlak tesiri yapmakta ve kırılma deneyleri sırasında kırılmanın başlamasında ve ilerlemesinde katkı sağlamaktadır. Şekil 7'deki SEM mikroskobu görüntüsünde kompozit yapı içerisindeki keskin köșeli $\mathrm{MgO}$ parçacıkları ve meydana gelen poroziteli bölge görünmektedir.

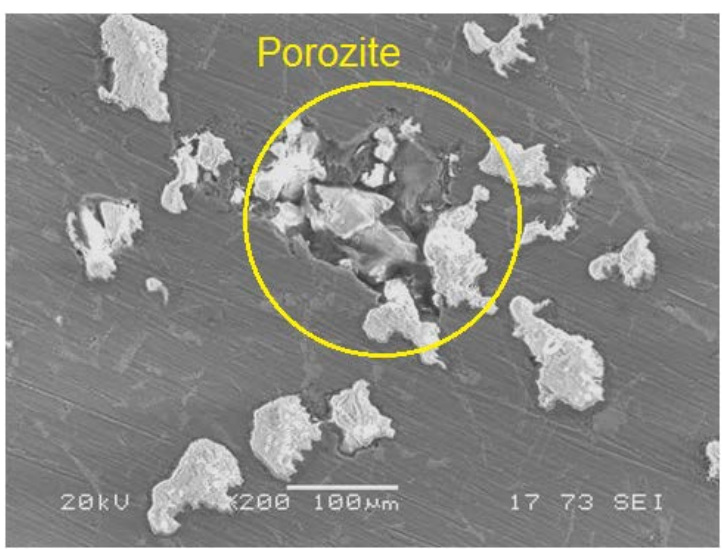

Şekil 7. Kompozit yapı içerisindeki $\mathrm{MgO}$ parçacıkları ve porozif bölge [18]

Yukarıdaki bahsedilen nedenlerin dışında bir başka husus ta kompozitlerin üretim yöntemleri arasındaki farlılıktır. KD ve Vİ yöntemleri sıvı faz üretim yöntemi içerisinde yer alırken TM yöntemi ise katı faz üretim yöntemidir. $\mathrm{KD}$ ve VI yöntemlerinde $750{ }^{\circ} \mathrm{C}$ 'ye kadar isttılan sıvı metalin takviye elemanı olan $\mathrm{MgO}$ parçacıklarını ıslatması ve yüksek sıcaklığın tesiriyle matris takviye ara fazı, TM yöntemine göre biraz daha güçlü oluşabilmektedir. TM yönteminde her ne kadar sinterleme 1 sıll işlemi yapılmış olsa da diğer iki yöntemde olduğu kadar sıcaklığın etkisi olamamakta, olan etki ise genellikle matris elemanı parçacıkları arasındaki bağlanmaya yardım etmektedir. Bu durumda ergime derecesi matris elemanına göre çok yüksek olan $\mathrm{MgO}$ takviye parçacıkları yeterince 1slatılamamakta ve kompozit yapı içerisinde matris malzemesi alüminyumdan bağımsız hareket edebilmektedir. Dolayısıyla çapraz kırılma deneylerinde uygulanan yükün tesiri ile eğilen kompozit yapı içerisindeki $\mathrm{MgO}$ parçacıklarının yoğun olduğu bölgelerin mukavemeti ciddi seviyede azalmaktadır. Yapılan bu değerlendirmelerden sonra, kırılma dayanımı yönünden en iyi performansı KD kompozit üretim yöntemi, en düşük performansı ise TM kompozit üretim yönteminin sergilediği anlaşılmaktadır.

\subsection{Aşınma Kayıpları}

Yapılan deneysel çalışmanın son aşamasında üç farklı $\mathrm{MgO}$ takviye oranında üretilmiş olan kompozit numunelerin abrasif aşınma performanslarını belirlemek üzere yapılan deneylerden elde edilen aşınma kaybı değerlerini gösteren grafikler Şekil 8'de verilmiştir.

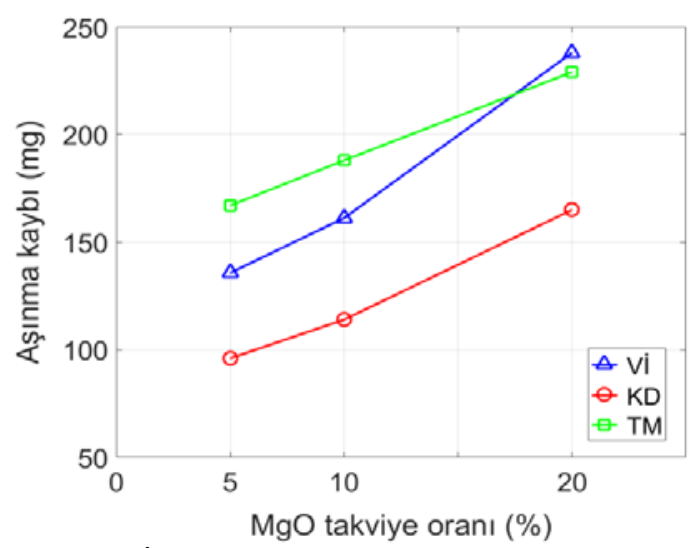

Şekil 8. Vİ, KD ve TM ile üretilen kompozitlerin $\mathrm{MgO}$ takviye oranına göre aşınma kayıpları

Şekil 8'deki grafik incelendiğinde, genel olarak $\mathrm{MgO}$ takviye miktarındaki artışa bağlı olarak aşınma kaybı değerlerinde artış meydana gelmiştir. Literatürde benzer sonuçlar yer almaktadır [25-27]. Bunun en önemli sebebi artan takviye oranlarıyla birlikte porozite miktarlarının da artması ve kompozit yapının tokluk miktarının düşmesidir. Aşınma deneylerinde kompozit yapı içerisindeki porozite boşlukları aşındırıcı zımpara taneciklerinin işini kolaylaştırmış̧ır. Çok sert fazdaki $\mathrm{Al}_{2} \mathrm{O}_{3}$ aşındırıcı tanecikleri kompozit 
yapıdaki gözeneklere girerek daha rahat talaş kaldırmış ve aşınma miktarlarını arttırmıştır. $[25,26]$. Kompozit numunelerdeki yüksek porozite miktarının aşınma kayıplarını doğrudan etkilediği söylenebilir.

Abrasif aşınma deneylerinde en yüksek performansı KD yöntemiyle üretilmiş kompozitler gösterirken, en düşük performans TM yöntemiyle üretilen kompozitlerden elde edilmiştir. Kompozit numunelerin aşınma ve çapraz kırılma deney sonuçları birbirini desteklemektedir. Çünkü, her iki mekanik deney sonuçlarını etkileyen temel unsur kompozit yapılardaki porozite miktarlarıdır.

\section{SONUÇLAR}

Yapılan deneysel çalışmadan elde edilen sonuçlar aşağıda sıralanmıştır:

Vİ, KD ve TM kompozit üretim yöntemlerinin hepsinde kompozit yapı içerisindeki MgO takviye miktarının artmasıyla porozite (gözenek) miktarları yükselmiştir. En düşük porozite miktarı Vİ yöntemiyle üretilen alüminyum kompozitte elde edilmiştir.

Sertlik değerleri $\mathrm{MgO}$ takviye miktarının artmasıyla genel olarak yükselmiştir. Bu durum Vİ yönteminin özelliğinden kaynaklanan durum sebebiyle sadece \%20 MgO takviyeli kompozitte farklılık göstermiştir. En yüksek sertlik değeri KD numunede ölçülürken en düşük sertlik TM kompozit numuneden elde edilmiştir.

Vİ, KD ve TM kompozit üretim yöntemlerinin tümünde üretilen kompozit malzemeler içerisindeki $\mathrm{MgO}$ takviye miktarının artmasıyla kırılma yükü (dayanımı) kayda değer miktarda azalmıştır. En yüksek kırılma yükü KD numunede ölçülürken en düşük kırılma yükü TM kompozit numuneden kaydedilmiştir.

Kompozitlerin aşınma kayıpları MgO takviye miktarının artmasıyla genel olarak artmıştır. En az aşınma kaybı KD kompozit numuneden ölçülürken en fazla kayıp TM numuneden meydana gelmiştir.
Üç farklı yöntemle fakat aynı takviye elmanı ve takviye oranlarıyla üretilen kompozitlerin mekanik deney sonuçlarını, yapılarındaki porozite miktarlarının önemli derecede etkilediği genel sonucuna varılmıştır.

Yapılan bu değerlendirmeler sonucunda üç farklı yöntemle üretilen kompozit malzemelerin mekanik performanslarını toplu halde gösterim Çizelge 2'de verilmiştir. Tabloya göre en yüksek mekanik performans $\mathrm{KD}$ yönteminden elde edilirken en düşük performansı TM yöntemi sergilemiştir.

\begin{tabular}{|c|c|c|c|c|}
\hline \multicolumn{2}{|c|}{$\begin{array}{r}\text { Çizelge 2. Mekanik } \\
\text { çizelgesi }\end{array}$} & \multicolumn{2}{|c|}{ performans } & karşılaştırma \\
\hline Yöntem & $\begin{array}{c}\text { En Az } \\
\text { Porozite }\end{array}$ & $\begin{array}{c}\text { En } \\
\text { Fazla } \\
\text { Sertlik }\end{array}$ & $\begin{array}{c}\text { En } \\
\text { Yüksek } \\
\text { Kırılma } \\
\text { Yükü } \\
\end{array}$ & $\begin{array}{c}\text { En Az } \\
\text { Aşınma } \\
\text { Kaybı }\end{array}$ \\
\hline $\mathbf{V I}$ & & & & \\
\hline KD & & & & \\
\hline TM & & & & \\
\hline Yöntem & $\begin{array}{c}\text { En } \\
\text { Fazla } \\
\text { Porozite }\end{array}$ & $\begin{array}{l}\text { En Az } \\
\text { Sertlik }\end{array}$ & $\begin{array}{c}\text { En } \\
\text { Düşük } \\
\text { Kırılma } \\
\text { Yükü }\end{array}$ & $\begin{array}{c}\text { En } \\
\text { Fazla } \\
\text { Aşınma } \\
\text { Kayb1 }\end{array}$ \\
\hline $\mathbf{V I}$ & & & & \\
\hline KD & & & & \\
\hline TM & & & & \\
\hline
\end{tabular}

\section{KAYNAKLAR}

1. Pul, M., 2010. Al Matrisli MgO Takviyeli Kompozitlerin İnfiltrasyon Yöntemi ile Üretilmesi ve İşlenebilirliğinin Değerlendirilmesi, Gazi Üniversitesi Fen Bilimleri Enstitüsü, Doktora Tezi, Ankara.

2. Aydın, H., 2005. MgO Parçacık Takviyeli Alümiyum Matris Kompozit Malzemelerin Geliştirilmesi, G.Ü. Fen Bilimleri Enstitüsü, Yüksek Lisans Tezi, Ankara.

3. Acılar, M., 2002. Al/SiC Kompozitlerin Vakum İnfiltrasyon Yöntemi ile Üretimi ve Aşınma Davranışlarının Araştırılması, G.Ü. Fen Bilimleri Enstitüsü, Doktora Tezi, Ankara.

4. Montoya-Dávila, M., Pech-Canul, M.A., PechCanul, M.I., 2007. Effect of bi-andtrimodal Size Distribution on the Superficial Hardness 
of $\mathrm{Al} / \mathrm{SiCp}$ Composites Prepared by Pressureless Infiltration, Powder Technology, 176, 66-71.

5. Demir, A., Altinkok, N., 2004. Effect of Gaspressure Infiltration on Microstructure and Bending Strenght of Porous $\mathrm{Al}_{2} \mathrm{O}_{3} / \mathrm{SiC}$ Reinforced Aluminium Matrix Composites, Composites Scienceand Technology, 64, 2067-2074.

6. Hashim, J., Looney, L., Hashmi, M.S.J., 2001. The Enhancement of Wettability of SiC particles in Cast Alüminium Matrix Composites, Journal of Materials Processing Technology, 119, 329-335.

7. Sur, G., Şahin, Y., Gökkaya, H., 2005. Ergimiş Metal Karıştırma ve Basınçlı Döküm Yöntemi ile Alüminyum Esaslı Tanecik Takviyeli Kompozitlerin Üretimi, Gazi Üniv. Müh. Mim. Fak. Der., 20(2), 233-238.

8. Davidson, A.M., Regener, D., 2000. A Comparison of Aluminium-based Metal-matrix Compositesrein Forced with Coatedandun Coated Particulate Siliconcarbide, Composites Scienceand Technology, 60, 865-869.

9. Günay, M., 2009. Toz Metalurjisi Yöntemi ile Üretilmiş Al-Si/SiCp Kompozitlerin Mekanik ve İşlenebilirlik Özelliklerinin Araştırılması, Gazi Üniversitesi Fen Bilimleri Enstitüsü, Doktora Tezi, Ankara.

10. Hanumanth, G.S., Irons, G.A., 1993. Particle Incorporation by Melt Stirring for the Production of Metal-matrix Composites, Journal of MaterialsScience, 28(9), 2459-2465.

11. Hashim, J., Looneyand, L., Hashmi, M.S.J., 2002. Particle Distribution in Cast Metal Matrix Composites-Part I, Journal of Materials Processing Technology, 123, 251-257.

12. Tham, L.M., Gupta, M., Cheng, L., 1999. Influence of Processing Parameters During Disintegrated Melt Deposition Processing on Near Net Shape Synthesis of Aluminium Based Metal Matrix Composites, Materials Scienceand Technology, 15, 1139-1146.

13. Kok, M., 2005. Production and Mechanical Properties of $\mathrm{Al}_{2} \mathrm{O}_{3}$ Particle-reinforced 2024 Aluminium Alloy Composites, Journal of Materials Processing Technology, 161, 381-387.
14. Naher, S., Brabazon, D., Looney, L., 2005. Development and Assessment of a New Quick Quench Stir Caster Design for the Production of Metal Matrix Composites, Journal of Materials Processing Technology, 166(3), 430-439.

15. Bindumadhavan, P.N., Chia T.K., Chandrasekaran, M., Heng Keng Wah, Loh N.L., Prabhakar, O., 2001. Effect of Particleporosity Clusters on Tribological Behavior of Cast Aluminum Alloy A356-SiCp Metal Matrix Composites, Materials Scienceand Engineering A, 315, 217-226.

16. Balasivanandha Prabu, S.,Karunamoorthy, L., Kathiresan, S., Mohan, B., 2006. Influence of Stirring Speed and Stirring Time on Distribution of Particles in Cast Metal Matrix Composite, Journal of Materials Processing Technology, 171, 268-273.

17. Pul, M., 2013. Evaluation of the Relationship Betweenthe Cutting Force Components of $\mathrm{Al} / \mathrm{MgO}$ Composites Produced by Infiltration, Arab J Sci Eng. 38, 1179-1189.

18. Pul, M., 2013. The Effect of MgO Ratio on Surface Roughness in Al-MgO Composites Materialsand Manufacturing Processes, 28, 963-968.

19.http://web.hitit.edu.tr/dosyalar/materyaller/emin erdin@hititedutr240520183C0N2X3Z.pdf

20.TS EN ISO 4498, 2011. Sinterlenmiş Metal Malzemeler (Sert Metaller Hariç)-Görünen Sertliğin ve Mikrosertliğin Tayini, Türk Standartları Enstitüsü, Ankara.

21. TS EN ISO 6506-1, 2007. Metalik Malzemeler-Brinell Sertlik Deneyi-Bölüm 1: Deney Metodu, Türk Standartları Enstitüsü, Ankara.

22. ASTM B528-05, 2008. Standard Test Method for Transverse Rupture Strength of Metal Powder Specimens, ASTM International, USA.

23. Pul, M., 2013. The Effect of MgO Ratio on Surface Roughness in Al-MgO Composites, Materials and Manufacturing Processes, 28, 963-968.

24. Pul, M., 2018. Investigation of Effects of MgO Ratio on the Surface Quality and Tool Wear in Turning Al-MgO Composites, Proc I Mech E Part B: Journal of Engineering Manufacture, 232(12), 2122-2131. 
25. Pul, M., 2019. Toz Metalurjisi Yöntemiyle Üretilen $\mathrm{B}_{4} \mathrm{C}+\mathrm{TiB}_{2}$ Takviyeli Al 2024 Esaslı Kompozitlerde Takviye Miktarının Mekanik Özelliklere Etkisi, Uluslararası Mühendislik Araştırma ve Geliştirme Dergisi,11(1), 87-98.

26. Baydaroğlu, V., Pul, M., 2018. Effect of Reinforcement Ratios on Mechanical Properties and Wear Behavior of B4C + SiCReinforced AA 7075 Composites, TURKEYTRIB'18 2nd International Conference on Tribology, 18-20 April, 80-91, İstanbul.

27. Pul, M., 2019. Alüminyum 7075 Matrisli Kompozitlerde SiC, $\mathrm{B}_{4} \mathrm{C}$ ve $\mathrm{TiB}_{2}$ Takviye Elemanlarının Mekanik Özelliklere Etkilerinin Karşılaştırılması, Düzce Üniversitesi Bilim ve Teknoloji Dergisi, 7, 180-193. 
